\title{
The use of participatory action research to improve energy intake of the soccer athletes
}

\author{
Irwan Budiono*, Arif Setiawan, Arif Rahmat Kurnia \\ Universitas Negeri Semarang. Sekaran, Kec. Gunung Pati, Semarang, Jawa Tengah 50229, Indonesia \\ * Corresponding Author. Email: irwan_budiono@staff.unnes.ac.id
}

Received: August 2, 2020; Revised: October 28, 2020; Accepted: November 11. 2020

\begin{abstract}
It was estimated that 5,3\% of Universitas Negeri Semarang (UNNES) soccer athletes were malnourished. The consumption survey results show that the average dietary energy intake (DEI) was $63.24 \%$ of the dietary reference intake (DRI). The purpose of this study was to improve the energy intake of athletes. This research was using a participatory action research method. The study was divided into 2 cycles which allocated in 30 days. This research was using a total sampling method. A total of 19 UNNES soccer athletes were involved as research subjects. Data on nutritional status and energy intake were analyzed to evaluate the success of participatory action research. Semi-Quantitative Food Frequency Questionnaire (SQ-FFQ) used to take dietary energy intake data, Nutrition status measured by BMI using Seca scales and microtome. A non-parametric test was used to analyze the success of the participatory action research program. Results showed that participatory action research can improve energy intake (EI) in athletes. Baseline data showed that the average percentage of DEI was $63.24 \%$ from the DRI. The average percentage of DEI increased became $71.38 \%$ at the end of the first cycle and rose into a $91.91 \%$ at the end of the second cycle. It is recommended for trainers to include nutrition assistance activities as part of the exercise program for athletes. Keywords: Participatory Action Research, Dietary Energy Intake, Soccer Athletes
\end{abstract}

How to Cite: Budiono, I., Setiawan, A., \& Kurnia, A. R. (2021). The use of participatory action research to improve energy intake of the soccer athletes. Jurnal Keolahragaan, 9(1), 76-85, doi:https://doi.org/10.21831/jk.v9i1.33697

\section{INTRODUCTION}

Sports achievements are the result of a gradual coaching effort. In Indonesia, sports coaching is carried out in stages according to region in the age group. The levels of sports coaching are implemented through coaching athletes starting from the city, provincial, to national level. Classification according to age stage is done through sports coaching for teenage athletes, students, and senior athletes. Adolescent athletes coaching is carried out by the Center for Student Sports Training Education (PPLOP). Similar guidance is also carried out for college students through the Student Sports Training Education Center (PPLM). All of the coaching programs are intended to recruit talented athletes so that they can become national athletes (Nababan et al., 2018; Soan, 2017).

Higher education institutions are expected to play a role in sports coaching. Therefore, universities are encouraged to foster student athletes in some numbers of excellent sports (Rasyono, 2016). Universitas Negeri Semarang (UNNES) as one of the universities that has the Faculty of Sport Sciences, also helps foster various student-level sports. One of the sports that is fostered by UNNES is soccer.

As with other sports, the performance of a soccer athlete is determined by many factors, one of which is the nutritional factor. Adequate nutritional intake will help athletes to achieve the best performance. Previous research has proven that nutrition plays a big role in improving sports performance. Research showed that adequate nutrition during their time on the training center was highly related with the ability to do physical and technical training (Sahlin, 2014). Adequate nutrition intake according to the training periodization has proven influential the athletes performance (Academy of Nutrition and Dietetics \& Dietitians of Canada, 2016). Providing proper nutrition care on the recovery period also proven to help restore the athlete's stamina (Penggalih \& Huriyati, 2007). Physical and technical training programs provided to athletes will be less optimal for athletes experiencing nutritional 
problems. Therefore the training program for athletes must be implemented comprehensively, involving various aspects including nutrition assistance activities (Budiono et al., 2019).

Preliminary studies conducted on UNNES soccer athletes showed the average body mass index (BMI) was $21.43 \pm 2.37$. From a total of 19 UNNES soccer athletes there was 1 person (5.3\%) with BMI included in the category of malnutrition. Preliminary studies also showed that $68.42 \%$ of athletes had dietary energy intake (DEI) below $70 \%$ of the dietary reference intake (DRI). The nutritional status profile and the level of energy consumption indicate the urgency of the nutrition assistance activities for UNNES soccer athletes.

Nutritional status and the dietary energy intake and nutrient intake are a theme of sports nutrition research that has been widely studied. These problems in nutrition research are grouped in the theme of macro nutrient deficiency. Some researchers have confirmed that the cause of malnutrition in athletes is an imbalance between energy intake compared with energy requirements. The energy needs of athletes are greater because this group requires additional energy to meet the energy needs of physical exercise activities (Condo et al., 2019). Therefore, efforts to solve malnutrition problems in athletes are to balance energy intake to match energy needs (Birkenhead \& Slater, 2015; Devlin et al., 2017; Granja et al., 2017).

The development of nutrition research throughout the world shows very rapid progress. Although the problem of macronutrient deficiency in athletes is a long-standing issue, in reality the problem of macronutrient deficiency in athletes is still a great deal to date (Condo et al., 2019; Setyawati et al., 2020; Vitale \& Getzin, 2019). There is still needed to have a scientific approach to overcome the problems caused by macronutrient deficiencies in athletes. Efforts to tackle problems due to macronutrient deficiencies in athletes require comprehensive approaches (Holway \& Spriet, 2011).

Comprehensive efforts in solving problems due to macronutrient deficiencies in athletes can be done by providing nutritional care individually. The application of nutrition care principles includes several activities, namely assessment, diagnosis, intervention, monitoring and evaluation. Within the framework of nutritional care, innovative strategies are needed to improve the level of nutritional consumption and nutritional status of athletes. This innovative strategy can be accommodated with action research designs (Sena et al., 2018; Sendall et al., 2018). Based on the background above, it is necessary to conduct research with a participatory research action approach to correct nutritional problems that occur in UNNES soccer athletes.

\section{METHODS}

\section{Design and Samples}

This study used a participatory action research design. The study was conducted in 2 cycles, where each cycle contained 4 steps, namely: planning - implementation - evaluation and reflection. In summary this action research design can be described on figure 1.

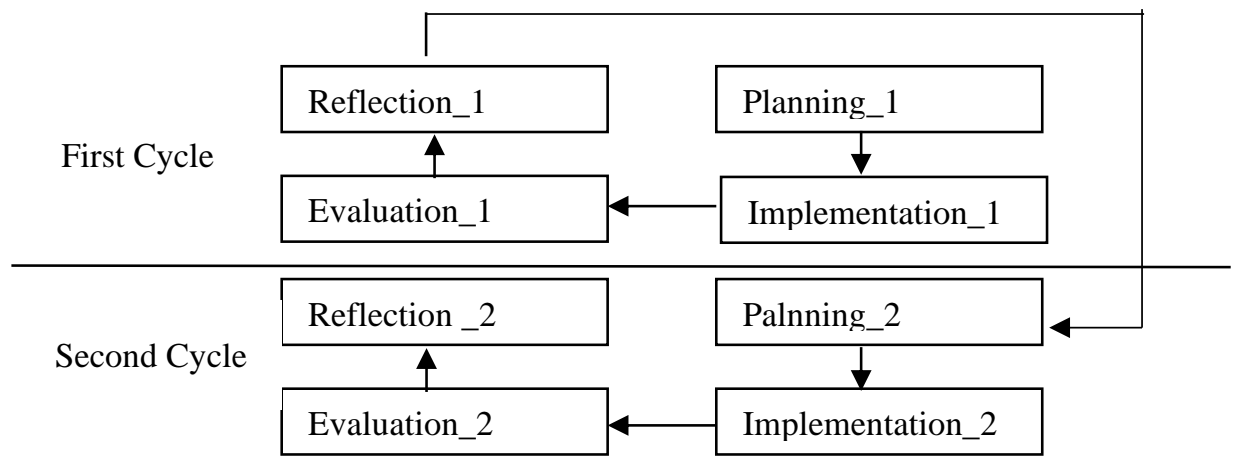

Figure 1. The Participatory Action Research Cycles

The research subjects were 19 UNNES soccer athletes. In total, the time allocated for the research team to carry out participatory action research was 30 days. The research team divided the allocated time to complete 2 action research cycles. 
The planning process in each cycle involves all athletes and the training team consisting of 1 head trainer and 2 assistant coaches. There are 2 objectives of the planning stage, namely 1) identifying nutritional problems faced by athletes, 2) compiling program plans to improve nutrition problems. At the implementation stage the athlete gets an intervention in accordance with the action planning that has been arranged in each cycle. At the end of the first cycle an evaluation of the success of the program is carried out. The results of the evaluation are used as reflection material for program planning in the second cycle.

\section{Focus on Action Planning}

The action plan in participatory action research is focused on efforts to improve the level of energy consumption of athletes. In general, the focus is implemented in the form of providing nutritional assistance to athletes. Details of the form of nutrition assistance in the first cycle are designed according to the nutritional problems faced in the cycle. The details of the form of nutrition assistance in the second cycle are based on the results of the evaluation and reflection of the results achieved in the previous cycle.

\section{Data Collection}

The study was conducted in July to August 2019. In the preliminary research before the program was implemented in the first cycle, data collection on nutritional status and energy consumption was carried out. Nutritional status data is taken by BMI, while DEI data is taken by semi quantitative food frequency questionnaire (FFQ) method. The FFQ method was chosen to obtain information on athletes' eating habits prior to the study.

At the preliminary research, demographic and socioeconomic data were also collected such as where athletes live, access to food services, and socioeconomic status. The data is needed as consideration for determining the program in action research.

At the end of each action research cycle, nutrition status and DEI data were collected. Nutritional status data is taken by BMI, while energy consumption level data is taken by 24-hours food recall method for 3 consecutive days at the end of the cycle.

In this study all weight data were measured using a brand stamped scale, while height was measured by microtoise. The anthropometric data is used to calculate BMI.

\section{Data Analysis}

In this study, nutritional status and DEI data were collected 3 times, namely in the initial stages before the implementation of the action research program, at the end of the first cycle, and at the end of the second cycle. Data on nutritional status and the DEI measured at each of these stages are analyzed univariately, by making a frequency distribution and size of the central tendency.

The effectiveness of participatory action research in improving athletes' DEI is done by analyzing the differences in nutritional status and DEI between the first cycle and the second cycle. Non-parametric test was used to analyze the success of participatory action research programs.

\section{RESULTS AND DISCUSSIONS}

\section{Preliminary Data on Nutritional Status and DEI of Soccer Athletes}

Preliminary data on nutritional status and DEI for athletes prior to starting the nutrition assistance program are shown in table 1 .

Table 1. Preliminary Data of Nutrition Status and Athletes' DEI

\begin{tabular}{llc}
\hline & Variables & n (\%) or Mean \pm SD \\
\hline Body Mass Index & & $21.43 \pm 2.37$ \\
Nutrition Status & Malnutrition (BMI < 18,5) & $1(5.26)$ \\
& Normal (IMT 18,5-25,0) & $18(94.74)$ \\
DEI Percentage (\% DRI) & & $63.24 \pm 5.95$ \\
DEI (\% DRI) & Undernourished (<70\% DEI) & $13(68.42)$ \\
& Good (70 - 110\% DEI) & $6(31.58)$ \\
\hline
\end{tabular}


The data in table 1 shows that there were athletes with poor nutritional status. The average percentage of DEI was also included as undernourished, which was $63.24 \%$ AKE. Malnutrition is a condition that develops due to an imbalance of energy and nutrient intake for a long time. The profile of the athletes' lack of energy consumption level needs to be corrected immediately so that it did not develop into malnutrition. Therefore, the focus in this action research was to emphasize the efforts to improve athletes' DEI.

\section{The Socioeconomic and Demographic Characteristics of Athletes}

The development of nutrition assistance design in the first cycle of action research was conducted by taking into account some of the socioeconomic and demographic characteristics of athletes. Table 2 presents information on age characteristics, socioeconomic status, athlete's residence, and access to food services.

Table 2. Socioeconomic and Demographic Characteristic of the Athletes

\begin{tabular}{llc}
\hline & \multicolumn{1}{c}{ Variables } & $\mathrm{n}(\%)$ or M \pm SD \\
\hline Age (years) & & $19.21 \pm 1.15$ \\
Socioeconomic Status* & KS III & $7(36.84 \%)$ \\
& KS III plus & $12(63.16 \%)$ \\
Residence & Parents' home & $5(26.32 \%)$ \\
& Student Dormitory & $2(10.53 \%)$ \\
Food Access & Boarding house & $14(73.68 \%)$ \\
& Prepared by family or catering & $2(10.53 \%)$ \\
& Self-cooked/ self-bought & $12(63.16 \%)$ \\
& The combination of eating at home and buying & $5(26,32 \%)$ \\
\hline
\end{tabular}

* The criteria refer to the family welfare category determined by the government, consisting of 4 Family Welfare Criteria (KS), namely: KS I = limited to meeting Basic Needs; KS II = up to the level of Psychological Needs Fulfillment; KS III = up to the level of Developmental Needs Fulfillment; KS III plus = reaches the level of Self Esteem Fulfillment (BKKBN, 2010).

The socioeconomic and demographic information shown in table 2 was used as input for the research team in preparing a nutrition assistance plan. Table 2 showed that athletes did not live in one training camp, most athletes lived in boarding houses. Access to eating services for athletes were not centralized by the institution. Most access to food was obtained self-cooked or self-bought from food stalls around the campus.

The meal management system for athletes that were not managed institutionally was a determinant factor in controlling athletes' dietary adherence. However, the situation must be managed in such a way that the athletes' energy intake can still be improved. Parental support for their children who become athletes were needed. The support includes providing adequate food intake for the children's nutritional needs. Data in table 2 shows that all parents of athletes are included in the category of a prosperous family (KS III and KS III plus). Family Welfare Category refer to indicators used by the government in determining the criteria for a prosperous family. There are 4 criteria used in the mapping of welfare families, which were called welfare families I (KS I), welfare families II (KS II), welfare families III (KS III), and welfare families III plus (KS III plus). The main characteristic of families that were included in the KS III plus category is that the family has reached the stage of fulfilling self-actualization needs, such as making financial contributions on a regular and active basis in managing community organizations (BKKBN, 2010). The data in table 2 shown that all athletes came from category III and III plus welfare families. The family welfare background of each athlete showed that financially, the family could support the fulfillment of the nutritional needs of their children as athletes.

\section{Nutrition Assistance in the First Cycle}

Nutrition assistance activities in the first cycle were carried out for 2 weeks. Nutrition assistance was carried out by considering the socioeconomic and demographic characteristics, athletes' nutritional status and DEI profile. Based on these considerations, the researchers formulated 2 forms of activity in nutrition assistance. The forms of nutrition assistance are 1) training on menu planning for athletes, 2) providing nutritional counseling. Training on menu planning for athletes were conducted by lecturing 
and discussing methods, as well as giving a nutrition pocket book to each athlete. The aim of the training was to increase the athletes' knowledges and skills in translating dietary instructions provided by nutritionists. The nutrition counseling for athletes was carried out by registered nutritionists. Counseling was carried out with the aim to provide nutrition advice to athletes who have difficulty in implementing nutrition planning for each individual. This counseling activity was carried out 2 times in 2 weeks of nutrition assistance.

\section{Summary of the Results of Problem Identification, Action Plans, Program Implementation, and Evaluation Results in the First Cycle}

The first cycle of research activities in the form of problem identification, preparation of action plans, implementation of nutrition assistance programs, and evaluation of results can be seen in the following table 3 .

Table 3. Problems, Action Plans, Implementations, and Results of the First Cycle

\begin{tabular}{|c|c|c|c|}
\hline Problems & Action Plans & Implementations & Results \\
\hline $\begin{array}{l}\text { 1. There were athletes } \\
\text { with nutritional } \\
\text { problems (BMI } \\
<18.5 \text { ). } \\
\text { 2. Dietary energy } \\
\text { intake did not meet } \\
\text { the needs of } \\
\text { athletes. }\end{array}$ & $\begin{array}{l}\text { 1. Need to increase } \\
\text { knowledge and skills } \\
\text { about nutrition in } \\
\text { athletes. } \\
\text { 2. The need for } \\
\text { nutritional } \\
\text { counseling to guide } \\
\text { athletes in achieving } \\
\text { the target of } \\
\text { improving dietary } \\
\text { energy intakes. }\end{array}$ & $\begin{array}{l}\text { 1. } \begin{array}{l}\text { Menu planning } \\
\text { workshops for } \\
\text { athletes. }\end{array} \\
\text { 2. Provision of } \\
\text { nutrition pocket } \\
\text { books. } \\
\text { 3. Providing nutrition } \\
\text { counseling } \\
\text { individually } 2 \text { times } \\
\text { in the span of } 2 \\
\text { weeks of assistance. }\end{array}$ & $\begin{array}{l}\text { 1. Athletes who at the } \\
\text { preliminary research } \\
\text { identified malnutrition, } \\
\text { at the end of the first } \\
\text { cycle the nutritional } \\
\text { status did not changed. } \\
\text { 2. Based on 24-hours food } \\
\text { recall during the last } 3 \\
\text { days of the action } \\
\text { research cycle, the } \\
\text { average DEI percentage } \\
\text { was } 71.38 \% \text { DRI. } \\
\text { 3. Athletes still had } \\
\text { difficulty implementing } \\
\text { dietary recommendations } \\
\text { into the menu that was } \\
\text { actually consumed. }\end{array}$ \\
\hline
\end{tabular}

The results of the implementation of the nutrition assistance activities in the first cycle as shown in table 3 showed an average percentage of DEI of $71.38 \%$. Even though this achievement had not met the target, it had shown an improvement compared to the average percentage of DEI at the beginning of the first cycle. Not yet achieved the target level of energy consumption in athletes because some athletes still had difficulty implementing nutritional recommendations into the menu that was actually consumed.

Difficulties in implementing recipes given by nutritionists occur in many athletes. Several studies had shown a perception of the importance of certain types of nutrients, resulting in the intake of other nutrients that are less attention. For example, among athletes there was still an understanding that food sources of protein are more important than food sources of carbohydrates and fats (Condo et al., 2019; Jagim et al., 2019). This incorrect perception results in athletes did not getting a balanced food intake. This imbalance in nutrient intake can ultimately lead to malnutrition. To prevent malnutrition in athletes, several studies recommend the importance of early detection. One of the early detection efforts that can be carried out was by monitoring the intake of energy and nutrients in athletes (Ihmels et al., 2009).

\section{Nutrition Assistance in the Second Cycle}

The results of nutrition assistance in the first cycle were used as reflection material for modification of nutrition assistance in the second cycle. The time allocation provided for nutrition assistance in this second cycle was 2 weeks. Modifications of the nutritional assistance model in the second cycle were 1) nutrition counseling about the use of food exchange units; 2) providing nutrition counseling; 3 ) monitoring athlete's food intake with 24-hours food recall method; 4) evaluation of the results of monitoring athletes' food intake by involving the trainer.

Nutrition counseling about the use of food exchange units was done to help athletes to better understand how to translate energy needs into the amount and type of food that must be consumed. 
Nutrition counseling activities carried out in the first cycle continue to be in the second cycle. Nutrition counseling was intended to provide nutritional advice to athletes who have difficulty in implementing individual nutrition planning.

The next modification of the nutrition assistance program was monitoring and evaluating the athletes' food intake by involving the trainer. Monitoring was carried out by conducting a consumption survey using the 24-hours food recall method every day during mentoring. The results of the consumption survey were evaluated together by involving trainers - athletes - and nutritionists.

\section{Educating material for food exchange units}

The obstacle faced by athletes during the nutrition assistance period was the difficulty in implementing the results of calculating energy requirements into food that needs to be consumed. Nutrition instructions in the form of a number of weight units of food that need to be consumed were less understood by athletes. Therefore, in the second cycle of this action research, counseling was conducted with material about the food exchange unit. Table 4 below was made as an estimation of the number of food exchange units for several energy needs in a day.

Table 4. Food Exchange Units for Meeting Daily Energy Needs

\begin{tabular}{ccccccccc}
\hline $\begin{array}{c}\text { Energy Requirements } \\
\text { (kkal) }\end{array}$ & \multicolumn{7}{c}{ Food Exchange Units according to Food Groups } \\
\hline 4000 & 9 & 6 & 6 & 5 & 6 & 5 & 4 & 5 \\
4100 & 9,5 & 6 & 6 & 5 & 6 & 5 & 4 & 5 \\
4200 & 9,5 & 6 & 7 & 6 & 6 & 5 & 4 & 5 \\
4300 & 9,5 & 6,5 & 7 & 6 & 6 & 5 & 5 & 5 \\
4400 & 10 & 6,5 & 7 & 6 & 6 & 5 & 5 & 5 \\
4500 & 10 & 7 & 7 & 6 & 7 & 5 & 5 & 6 \\
4600 & 10 & 7 & 8 & 6 & 7 & 5 & 5 & 6 \\
4700 & 10 & 8 & 8 & 6 & 7 & 5 & 5 & 6 \\
4800 & 10,5 & 8 & 8 & 6 & 7 & 5 & 5 & 7 \\
4900 & 10,5 & 8,5 & 8,5 & 6 & 7 & 5 & 6 & 6 \\
5000 & 10,5 & 8,5 & 9 & 6 & 8 & 5 & 6 & 6 \\
\hline
\end{tabular}

Legends:

Carb. $=$ carbohydrate, $\mathrm{AP}=$ Animal Protein, $\mathrm{VP}=$ Vegetable Protein, Veg. $=$ Vegetables

Knowledge of the food exchange unit will help athletes to consume food according to nutritional needs. Based on table 4, an athlete could adjust the fulfillment of energy and nutrient requirements by using a number of food exchange units. For example, athletes with a daily energy requirement of 4000 Kcal, then their nutritional needs will be fulfilled by consuming 9 units of carbohydrate exchange, 6 units of animal protein exchange, 6 units of vegetable protein exchange, 6 units of vegetable exchange, 5 units of vegetable exchange, 6 units of exchange, milk as much as 5 exchange units, oil as much as 4 exchange units, and sugar as much as 5 exchange units.

Based on table 4, for energy needs as much as $4000 \mathrm{Kcal} /$ day, athletes were encouraged to consume as much as 9 units of carbohydrate exchangers. This means that these athletes need to consume 9 food changers in one day as a source of carbohydrates. The selected carbohydrate source can adjust to the desired or availability of food ingredients. For example, 1 carbohydrate exchangers can be made in the form of 100 grams of rice ( $3 / 4$ cups), or the equivalent of 200 grams of potatoes ( 2 medium sizes).

\section{Summary of the Results of Problem Identification, Action Plans, Program Implementation, and Evaluation Results in the Second Cycle}

After evaluating and reflecting on the results of nutrition assistance in the first cycle, further steps were taken to improve the nutritional assistance model in the second cycle. Table 5 summarizes the results of the action research activities in the second cycle. 
Jurnal Keolahragaan 9 (1), 2021 - 82

Irwan Budiono, Arif Setiawan, Arif Rahmat Kurnia

Table 5. Problems, Action Plans, Implementations, and Results of the Second Cycle

\begin{tabular}{|c|c|c|c|}
\hline Problems & Action Plans & Implementations & Results \\
\hline $\begin{array}{l}\text { 1. There were still } \\
\text { malnourished } \\
\text { athletes (BMI } \\
<18.5 \text { ). } \\
\text { 2. Athletes unable to } \\
\text { improve their \% } \\
\text { DEI optimally } \\
\text { (only reached } \\
\text { 71.38\%). }\end{array}$ & $\begin{array}{l}\text { Modification of the } \\
\text { nutrition assistance } \\
\text { model for athletes was } \\
\text { needed through: } \\
\text { 1. Nutrition education } \\
\text { about the use of food } \\
\text { exchange units. } \\
\text { 2. Nutrition counseling. } \\
\text { 3. Involvement of } \\
\text { trainers in } \\
\text { monitoring and } \\
\text { evaluating athletes' } \\
\text { food intake. }\end{array}$ & $\begin{array}{l}\text { 1. Nutrition } \\
\text { counseling about } \\
\text { the use of food } \\
\text { exchange units. } \\
\text { 2. Provision of } \\
\text { nutrition } \\
\text { counseling. } \\
\text { 3. Monitoring the } \\
\text { athletes' dietary } \\
\text { intake with the 24- } \\
\text { hours food recall } \\
\text { method. } \\
\text { 4. Evaluate the results } \\
\text { of monitoring the } \\
\text { athletes' dietary } \\
\text { intake by involving } \\
\text { the trainer. }\end{array}$ & $\begin{array}{l}\text { 1. In general, athletes } \\
\text { succeed in improving } \\
\text { the percentage of DEI } \\
\text { approaching the energy } \\
\text { needs of each athlete } \\
\text { (averaged DEI = } \\
91.91 \% \text { ). } \\
\text { 2. BMI in } 1 \text { athlete who } \\
\text { was suffering from } \\
\text { malnutrition cannot be } \\
\text { increased to the normal } \\
\text { nutrition category, but } \\
\text { the percentage of DEI } \\
\text { had significantly } \\
\text { increased. }\end{array}$ \\
\hline
\end{tabular}

The results of the implementation of participatory action research in the second cycle show that with intensive nutrition assistance, improvement in athletes' nutrition can be achieved in stages. The data in Table 5 shows the average percentage of DEI has increased from $71.38 \%$ in the first cycle to $91.91 \%$ in the second cycle. The increase can be interpreted that the implementation of nutrition assistance programs in action research has succeeded in solving research problems.

Compared to the first cycle, DEI improvement in athletes seems to be faster in the second cycle. This shows that intense modification of nutrition assistance activities can improve diet adherence to athletes. Modifications of nutritional assistance given in the second cycle include: 1) the athletes' food intake assessment every day, 2) the results of the food intake assessment by nutritionists were analyzed and disseminated to the trainer, 3 ) if the results of the daily nutrition intake assessment indicate the athlete's food intake not in accordance with the recommendation, then counseling and motivation are given by the trainer.

\section{The Effectiveness of Participatory Action Research in Improving Nutritional Status and DEI of Athletes}

The effectiveness of the nutrition assistance activities in the action research cycle can be seen from the results of the statistical analysis in table 6 .

Table 6. Differences in Nutritional Status and DEI at The Beginning of The Cycle, The End of The First Cycle and The End of The Second Cycle

\begin{tabular}{|c|c|c|c|c|c|}
\hline \multicolumn{2}{|c|}{ Variables } & $\begin{array}{c}\text { Preliminaries } \\
\mathrm{n}(\%) \text { atau Mean } \\
\pm \text { SD (range) }\end{array}$ & $\begin{array}{c}\text { First Cycle } \\
\mathrm{n}(\%) \text { atau } \mathrm{M} \pm \mathrm{SD}\end{array}$ & $\begin{array}{c}\text { Second Cycle } \\
\mathrm{n}(\%) \text { atau } \mathrm{M} \pm \mathrm{SD}\end{array}$ & $p$ value \\
\hline \multicolumn{2}{|l|}{ BMI } & $21.43 \pm 2.37$ & $21.47 \pm 2.23$ & $21.53 \pm 2.17$ & $\begin{array}{l}>0.05^{1)} \\
>0.05^{2)}\end{array}$ \\
\hline \multirow{2}{*}{$\begin{array}{l}\text { Nutrition } \\
\text { Status } \\
\text { Category } \\
\end{array}$} & Malnutrition & $1(5.3)$ & $1(5.3)$ & $1(5.3)$ & \multirow{2}{*}{$\begin{array}{l}>0.05^{1)} \\
>0.05^{2)}\end{array}$} \\
\hline & Normal & $18(94.7)$ & $18(94.7)$ & $18(94.7)$ & \\
\hline \multicolumn{2}{|c|}{$\begin{array}{l}\text { Average Percentage of Dietary } \\
\text { Energy Intake }\end{array}$} & $63.24 \pm 5.95$ & $71.38 \pm 2.45$ & $91.91 \pm 1.90$ & $\begin{array}{l}<0.01^{1)} \\
<0.001^{2}\end{array}$ \\
\hline $\begin{array}{l}\text { Dietary } \\
\text { Energy }\end{array}$ & $\begin{array}{l}\text { Malnourished }(< \\
70 \% \text { DEI) }\end{array}$ & $13(68.42)$ & $5(26.32)$ & 0 & \multirow{2}{*}{$\begin{array}{l}<0.01^{1)} \\
<0.01^{2)}\end{array}$} \\
\hline $\begin{array}{l}\text { Intake } \\
\text { Category }\end{array}$ & $\begin{array}{l}\text { Good }(70- \\
110 \% \text { DEI) }\end{array}$ & $6(31.58)$ & $14(73.68)^{3)}$ & $19(100.00)^{4)}$ & \\
\hline
\end{tabular}


Information:

Analysis was performed with nonparametric statistics, namely the Wilcoxson signed ranks test on the BMI variable and the percentage of DEI, Yates' corrected chi-square and fisher exact test on the nutritional status variable and the energy consumption level category. ${ }^{1)}$ analysis of preliminaries with the end of first cycle. ${ }^{2}$ analysis of the variables of the end of first cycle with the end of second cycle.

Table 6 shows that there were no significant differences in BMI variables after the nutrition assistance program was provided. The percentage of DEI showed a significant difference between the base line data with the first cycle, and between the first cycle and the second cycle. This shows the success of the participatory action research design in improving DEI in athletes.

The design of participatory action research has recently begun to be widely used for solving various health problems. Some studies also show the effectiveness of participatory action research designs to change the behavior of research subjects towards better one (Sena et al., 2018; Sendall et al., 2018). Action research was also considered appropriate for solving sports nutrition problems. The use of action research in several sport nutrition studies is carried out with the modification of an innovative intervention program. Innovative programs in action research in the field of sports nutrition include in the form of nutrition assistance using web-based applications, Android, and other tools to improve athletes' diet compliance (Budiono et al., 2018, 2019; Chen et al., 2015).

Based on observations during the action research process there are 4 factors that can indirectly improve the nutritional status of athletes. The four factors are 1) the existence of an intensive nutrition assistance program; 2) there is monitoring and evaluation of food intake in athletes; 3 ) sufficient duration of nutrition assistance; 4) interprofessional collaboration between trainers and nutritionists.

Nutrition assistance, monitoring and evaluation of food intake has been proven effective in improving energy consumption levels. The findings of this study confirm the results of previous studies, namely that continuous nutrition counseling activities can prevent unhealthy nutritional practices (Birkenhead \& Slater, 2015; Story et al., 2004). Good nutrition practices in athletes are shown by the athletes' skill in choosing the type and portion of food. These skills were a form of nutrition literacy in athletes. Nutrition literacy in athletes according to Cotugna et al. (2011) is the result of specific nutrition education according to the needs of each sport (Cotugna et al., 2011).

Practically the results of this study provide direction for improving the system of sports coaching. The nutrition assistance model in this action research can be used as a reference for solving nutritional problems that occur in athletes. Food services for athletes should ideally be done en masse with institutional food management techniques. In this study, research subjects access food independently. How to access food independently requires that athletes have the knowledge and skills to regulate food intake according to nutritional instructions. In practice, athletes' knowledge and skills on nutrition require the assistance of a nutritionist in sufficient time. Implementation of nutrition assistance in sufficient duration can change the nutritional behavior of athletes for the better. This is consistent with previous research which states that eating choices are dynamic, complex, and can change continuously. For this reason, athletes need to have skills in food selection (Birkenhead \& Slater, 2015; Charoenarparasmee et al., 2016). The findings of this study are also in line with the results of previous studies which explain that adherence to athlete diets can be improved by implementing intensive nutrition care programs and adequate time (Academy of Nutrition and Dietetics \& Dietitians of Canada, 2016; Budiono et al., 2019; Jagim et al., 2019).

This participatory action research shows that athlete compliance in implementing nutrition guidelines is also influenced by the coach's role. Closeness of psychological relationship can be utilized by the coach to motivate athletes to try to follow nutritional instructions. Several studies have proven the strong role of coaches in influencing athlete behavior. The results of this study reinforce the findings of previous research on socio-cognitive correlations between coaches-athletes (Davis et al., 2018; Scantlebury et al., 2018; Zaker \& Parnabas, 2018).

The practice carried out by nutritionists by involving trainers in evaluating athlete's food intake is a form of interprofessional collaboration. The collaboration between trainers and nutritionists in this study proved to play a major role in shaping healthy nutritional behavior in athletes. Previous research has revealed the importance of interprofessional collaboration in athlete coaching programs. Trainers and nutritionists each have different competencies. Both types of experts have a common mission, which is to assist athletes so that optimal performance can be achieved. Therefore, there is a need for synergy 
between various types of professions to support the achievement of sporting achievements (Bosch \& Mansell, 2015; Espinoza et al., 2018).

\section{CONCLUSIONS}

The research findings show that the nutrition program in participatory action research can significantly improve the athletes' DEI percentage. Based on the findings of the study, it is recommended that in the fostering of sporting achievements, elements of nutritional guidance should be included.

\section{REFERENCES}

Academy of Nutrition and Dietetics, \& Dietitians of Canada. (2016). Nutrition and Athletic Performance. Medicine and Science in Sports and Exercise, 48(3), 543-568. https://doi.org/10.1249/MSS.0000000000000852

Birkenhead, K. L., \& Slater, G. (2015). A Review of Factors Influencing Athletes' Food Choices. Sports Medicine, 45(11), 1511-1522. https://doi.org/10.1007/s40279-015-0372-1

BKKBN. (2010). Laporan Akhir Evaluasi Pelayanan Keluarga Berencana Bagi Masyarakat Miskin (Keluarga Prasejahtera/KPS dan Keluarga Sejahtera-I/KSI.

Bosch, B., \& Mansell, H. (2015). Interprofessional collaboration in health care: Lessons to be learned from competitive sports. Canadian Pharmacists Journal, 148(4), 176-179. https://doi.org/10.1177/1715163515588106

Budiono, I., Rahayu, T., Soegiyanto, \& Kurnia, A. R. (2019). Use of “ Nutriatlet ” Smartphone Application-based Personalized Nutrition Program to Improve Energy Consumption, Body Mass Index , and Body Fat Percentage among Martial Arts Athletes. Japanese Journal of Physical Fitness and Sports Medicine, 8(1), 29-35. https://doi.org/10.7600/jpfsm.8.29

Condo, D., Lohman, R., Kelly, M., \& Carr, A. (2019). Nutritional Intake, Sports Nutrition Knowledge and Football Players. Nutrients, 11, 1-13.

Cotugna, N., Snider, O. S., \& Windish, J. (2011). Nutrition assessment of horse-racing athletes. Journal of Community Health, 36(2), 261-264. https://doi.org/10.1007/s10900-010-9306-x

Davis, L., Appleby, R., Davis, P., Wetherell, M., \& Gustafsson, H. (2018). The role of coach-athlete relationship quality in team sport athletes' psychophysiological exhaustion: implications for physical and cognitive performance. Journal of Sports Sciences, 36(17), 1985-1992. https://doi.org/10.1080/02640414.2018.1429176

Devlin, B. L., Leveritt, M. D., Kingsley, M., \& Belski, R. (2017). Dietary intake, body composition, and nutrition knowledge of Australian football and soccer players: Implications for sports nutrition professionals in practice. International Journal of Sport Nutrition and Exercise Metabolism, 27(2), 130-138. https://doi.org/10.1123/ijsnem.2016-0191

Espinoza, P., Peduzzi, M., Agreli, H. F., \& Sutherland, M. A. (2018). Interprofessional team member's satisfaction: A mixed methods study of a Chilean hospital. Human Resources for Health, 16(1), 1-12. https://doi.org/10.1186/s12960-018-0290-z

Granja, D. S., Cotovio, R., Pinto, R., Borrego, R., Mendes, L., Carolino, E., Macedo, P., Ferreira, D., Caetano, C., \& Mendes, B. (2017). Evaluation of young elite soccer players food intake on match day and highest training load days. Journal of Human Sport and Exercise, 12(4), 1238-1247. https://doi.org/10.14198/jhse.2017.124.10

Holway, F. E., \& Spriet, L. L. (2011). Sport-specific nutrition: Practical strategies for team sports. Journal of Sports Sciences, 29(SUPPL. 1). https://doi.org/10.1080/02640414.2011.605459

Ihmels, M. A., Welk, G. J., Eisenmann, J. C., Nusser, S. M., \& Myers, E. F. (2009). Prediction of BMI change in young children with the family nutrition and physical activity (FNPA) screening tool. Annals of Behavioral Medicine, 38(1), 60-68. https://doi.org/10.1007/s12160-009-9126-3

Jagim, A. R., Zabriskie, H., Currier, B., Harty, P. S., Stecker, R., \& Kerksick, C. M. (2019). Nutrient Status and perceptions of energy and macronutrient intake in a Group of Collegiate Female Lacrosse Athletes. Journal of the International Society of Sports Nutrition, 16(1), 1-7. 
Jurnal Keolahragaan 9 (1), 2021 - 85

Irwan Budiono, Arif Setiawan, Arif Rahmat Kurnia

https://doi.org/10.1186/s12970-019-0314-7

Nababan, M. B., Dewi, R., \& Akhmad, I. (2018). Analisis Pola Pembinaan Dan Pengembangan Olahraga Rekreasi Di Federasi Olahraga Rekreasi Masyarakat Indonesia Sumatera Utara Tahun 2017. Jurnal Pedagogik Olahraga, 4(1), 38-55.

Penggalih, M. H. T., \& Huriyati, E. (2007). Gaya Hidup, Status Gizi dan Stamina Atlet pada Sebuah Klub Sepakbola. Berita Kedokteran Masyarakat, 23(4), 192-199.

Rasyono. (2016). Ekstrakurikuler Sebagai Dasar Pembinaan Olahraga Pelajar. Journal of Physical Education Health and Sport, 3(1), 44-49. https://doi.org/10.15294/jpehs.v3i1.6501

Sahlin, K. (2014). Muscle Energetics During Explosive Activities and Potential Effects of Nutrition and Training. Sports Medicine, 44(S2), 167-173. https://doi.org/10.1007/s40279-014-0256-9

Scantlebury, S., Till, K., Sawczuk, T., Weakley, J., \& Jones, B. (2018). Understanding the relationship between coach and athlete perceptions of training intensity in youth sport. Journal of Strength and Conditioning Research, 32(11), 3239-3245. https://doi.org/10.1519/JSC.0000000000002204

Sena, W., Nilvarangkul, K., Saranrittichai, K., Smith, J. F., Phajan, T., \& Seetangkham, S. (2018). Using Action Research to prevent work-related illness among rubber farmers in Northeastern Thailand. Public Health Nursing, 35(6), 466-472. https://doi.org/10.1111/phn.12526

Sendall, M. C., McCosker, L. K., Brodie, A., Hill, M., \& Crane, P. (2018). Participatory action research, mixed methods, and research teams: Learning from philosophically juxtaposed methodologies for optimal research outcomes. BMC Medical Research Methodology, 18(1), 1-6. https://doi.org/10.1186/s12874-018-0636-1

Setyawati, N., Dieny, F. F., Rahadiyanti, A., Fitranti, D. Y., \& Tsani, A. F. A. (2020). Profil antropometri, ketersediaan energi dan kepadatan tulang pada atlet remaja putri berbagai cabang olahraga. Jurnal Keolahragaan, 8(1), 21-31. https://doi.org/10.21831/jk.v8i1.30367

Soan, U. F. (2017). Kebijakan Dan Strategi Pembinaan Olahraga Prestasi Daerah. Jurnal Sains Keolahragaan Dan Kesehatan, 2(1), 20. https://doi.org/10.5614/jskk.2017.2.1.5

Vitale, K., \& Getzin, A. (2019). Nutrition and supplement update for the endurance athlete: Review and recommendations. Nutrients, 11(6), 1-20. https://doi.org/10.3390/nu11061289

Zaker, N. A., \& Parnabas, V. A. (2018). The correlation between coach-athlete relationship and motivation among Universiti Teknologi MARA (UiTM) Shah Alam athhletes. MoHE, 7(1), 153162. https://doi.org/10.15282/mohe.v7i1.173 